\title{
PHILOSOPHY OF LATE RENAISSANCE IN ENGLAND: HUMAN MORALITY
}

\author{
Shadmanov Kurban \\ qurbonjonsh@gmail.com \\ Bukhara State Medical Institute (Uzbekistan, Bukhara)
}

\begin{abstract}
Шадманов Курбан Бадриддинович
qurbonjonsh@gmail.com

Бухарский государственный медицинский институт (Узбекистан, Бухара)
\end{abstract}

\begin{abstract}
The author's purpose of the research is to visually show the timeline of philosophical development of ethical and moral laws, principles and concepts that have been identified and developed in different countries, among different peoples through the millenia history of mankind. As a particular subject of research English Late Renaissance philosophy appears. English philosophical traditions is presented with ones of the most oustanding studies of human and his nature. The study reflects the specificity and national originality of the process of the formation of ethics in England during the late Renaissance.

Key words: late Renaissance, category, individual, Homo sapiens, form, social being, concrete historical, national.
\end{abstract}

\section{Introduction}

Philosophy, particularly its ethical branch, like any other social-humanitarian phenomenon, has a historical character. Philosophical ethics is one of the oldest theoretical disciplines that arose as part of philosophy during the formation of slave societies. Ethical issues have been at the center of public attention since the advent of homo sapiens. Moreover, it is the emergence of ethical forms of relationships between individuals that gives us one reason to single out such a historical and sociological category as a reasonable person, to state his transition from a primitive state to a more developed one (Asmus V.F.; Antique culture; Losev; Annas; Bennet; Sharon; Parry; Watt; Wersicker). The problems of ethics as a science and a form of social life were undoubtedly considered at all stages of human civilization. However, every time and in every country the interpretations of ethical concepts and norms (and hence the terms.) Had a concrete historical and national character. In other words, those norms and actions that were considered ethical in Ancient Mesopotamia might not have been accepted in Ancient India, and the inhabitants of Ancient Egypt could hardly understand the very specific ethics of Ancient China. 
Let's move on to a brief analysis of the ethics of antiquity in the Middle Ages in order to understand the special role of ethics in the science and practice of later eras and, above all, the Renaissance and the New Age.

The purpose of the article is to clearly show that the laws, principles, concepts of ethics have been identified and developed over the course of millennia in different countries, among different peoples. The largest minds of mankind opened for us the depths of morality and the facets of beauty, since ethical education in their understanding is, first of all, and is an integral part of the comprehensive and harmonious development of the individual, regardless of time and circumstances. Based on this, the author set the main task - to explicitly show the place of the ethics of England of the late Renaissance in history and philosophy, starting from the initial stages of the process of its formation as a science.

\section{Research Methods and Methodology}

This research work is carried out on the basis of the historical-typological and structural-functional method, which provides for a combination of formal-logical and historical approaches through the prism of a culturology.

\section{Philosophy: the Study of Human and Morality}

It is known that ethics is a science that studies morality and ethics as expressions of public consciousness and forms of target behavior. Morality and ethics are the most important, fundamental features of the existence of human society. Ethics, like a number of other sciences, has experienced a number of paradoxes in its centuries-old history. The first philosophical science was physics, that is, the study of nature in the form of philosophical reasoning. Socrates became the founder of an independent ethical direction in philosophy. But it is characteristic of the life of terms that he did not use the very word "ethics" to denote a given direction of social thought, this was done later. Aristotle singled out ethics as a science, for which it is enough to recall his works such as "Nicomachean Ethics", "Great Ethics". However, practically before the Renaissance, ethics as an independent science did not exist $[1,2,3,4,5]$, i.e. it did not have its own systematized, ordered scientific and conceptual-terminological apparatus. For Aristotle, ethics was a science intermediate between psychology and politics. He believed that ethics heals the soul of a person and serves politics, and the main goal of politics is to create a democratic society.

The clarification of ethics like the development of philosophy in general was carried out gradually. The ancient Greeks usually divided philosophy into three parts, but each school did it in its own way. Some singled out physics, dialectics and logic, others - physics, dialectics and rhetoric, etc. Ethics, together 
with physics, logic, was first singled out by the Stoics. Such a division, coexisting along with others, has not disappeared (there have been many such disappearances in history), but gradually developed. It was also characteristic of medieval thinkers, thus reaching the Renaissance and Modern Times (Abelard, Chaucer, Thomas Aquinas, T. More, Fr. Bacon, Hobbes, Locke, Spinoza, Shaftesbury, Hutcheson, Hume, Helvetius, Edm. Spencer and others). The same can be traced in the concept of oriental thinkers of Islamic cultural orientation, i.e. in the philosophy of Eastern Peripatetism (IX-XIII cc.) represented by al-Kindi, Ibn Rushd, Ibn Tfeil, Beruni, Ibn Sina, Farabi, Yassavi, Gijduvani, Naqshbandi, etc.

In general, for antiquity and the Middle Ages, ethics was an integral part of philosophy, it was merged with them. Ethics was actually a concrete, practical science, the main task of which was the bodily and mental hygiene of life. In ancient-medieval ethics, naturalistic and moral trends were closely intertwined, and the former prevailed at first. Thus, a rather narrow understanding of the essence, goals and objectives of ethics as a science of human nature, the causes and forms of his actions $[6 ; 1 ; 4$, c. 56-126], existed for a very long time, until the late Renaissance and modern times. Even Spinoza, who wrote a special work - "Ethics" - actually identified this science with natural philosophy. Ethics was supposed to give a person advice on how to live correctly, including depending on divine decrees, and this was a feature of pre-Renaissance ethics.

And in the Middle Ages such a tradition prevailed when everything was subordinated to theology, and philosophy was recognized as its servant. The Church, God, Holy Scripture predetermined the solution of any problems in advance, including the place and role of man in this life. The questions of morality, morality, human values, etc. were resolved on the same paths. However, all these centuries, sometimes secretly, sometimes openly, there was a stubborn struggle of free thought with theological prejudices. Many philosophers of the Middle Ages (Augustine the Blessed, Thomas Aquinas, etc.) highly appreciated the freedom of the human mind. The development of ethical thought among Eastern and European philosophers in the Middle Ages gradually led to a revolution in the understanding of ethics in subsequent periods - in the Renaissance and the New Age. In the history of English philosophy, this is associated with the names of Duns Scott, T. More, F. Bacon, Thomas Hobbes, J. Locke, J. Berkeley, D. Hume, B. Spinoza, Shaftesbury, as well as W. Shakespeare, J. Donne, B. Johnson, J. Puttengham and others. It should be emphasized that this coup was not a coup only in ethics, it was a coup in all of science and in social practice. Science could not endlessly be in the narrow grip of religious thinking, this contradicted the very nature of science as a specific sphere of thought, as an objective form of reflection of life. The coup began with the discovery of Copernicus, who destroyed the geocentric picture of the world 
and created a heliocentric one. The right of the supreme judge was taken away from God, the planet Earth turned out to be immeasurably smaller than the Sun, moreover, revolving around it. The second circle of the new natural-scientific thinking closed on the very man, philosophy has become anthropocentric. The Copernican revolution had a tremendous impact on the entire historical process of the formation of the secular, bourgeois those historical conditions, worldview that contributed secularization of social views of the newly established society, the formation of a naturalistic, historically progressive in those social conditions understanding of social life and morality [7, c. 28].

The new science, developed by the followers of Copernicus, gave man the opportunity to realize his capabilities. It is extremely important that science helped to liberate ethics, and ethics - science. There was a process of mutually fruitful influence and mutual support in the struggle against a powerful rival - theology. With the Copernican coup, science for the first time challenged theology's right to monopolize the formation of a worldview. This was the first act in the process of penetration of scientific knowledge and scientific thinking into the structure of activity, man and society. All this had the most direct outputs to human independence, but already in the light of new ethical norms. Briefly and succinctly, this thought can be expressed in the following form - if earlier it was immoral to criticize God, now it has become immoral to humiliate a person [8, c. 8]. Thomas More, for example. The main idea of his "Utopia" is precisely ethics. Accordingly, the definition of happiness as the goal of human existence is the central philosophical problem of "Utopia". More philosophy, except ethical, More does not know and does not recognize [9, c. 137]. A person lives in order to be happy - this is his credo. Th.More understands nature as a workshop, and God as an architect in it. Therefore, he believes, a person can and should cognize this workshop and the creations existing in it, the most beautiful of which is himself. This approach fundamentally contradicted the medieval ethical postulates, which did not consider man to be anything equal to nature, and even more so to God.

Determining what is happiness and what are the goals of a person is an important task of any ethical teaching. Depending on how the problems of the origin and content of morality are solved, how it relates to the daily activities of a person, two directions can be distinguished in ethics - hedonistically demonistic and rigoristic. In ancient Greece, one of the first philosophers who followed the principles of hedonism in ethics were Democritus and Aristippus, as well as Epicurus and Lucretius. Rigorism (lat. Rigor "severity") - a kind of formalism in morality; a moral principle that characterizes the way of fulfilling the requirements of morality, which consists in strict and unswerving observance of certain moral norms, regardless of specific circumstances, in unconditional obedience to duty [10]. 
In the first direction, it is generally accepted that morality follows from the natural nature of man, his needs. This is opposed by the second understanding of ethics, characteristic of the ancient Eastern religions and the Middle Ages. Rigorists deny the very possibility of proceeding in ethics from the natural needs of man and consider morality to be something from the outside given to man, predetermined in advance, coming from God. Of course, in the era of the late Renaissance and modern times, the first point of view prevailed, although not in its pure form. Th. More considered it absurd to seek a harsh and inaccessible virtue, to exclude the joy of life and voluntarily endure suffering, from which there is no benefit. For the thinkers of the Renaissance, and then the New Age, ethics became the doctrine of a reasonable, happy and full-blooded life. This theory was put forward in opposition to asceticism - the most important manifestation of medieval ethics. It is known that asceticism preached voluntary isolation from earthly joys and blessings in the name of the afterlife, strict control of sensual drives and desires. Its main goal was to restrict a person from pleasures.

\section{English Renaissance Philosophy of Ethics}

Although in the English philosophical, socio-political and fictional literature of the XIV-XVII centuries, the concepts and terms of ethics are found quite often, nevertheless, this does not mean that the country's thinkers clearly understood the place of ethics in the general system of sciences and studied it as an independent direction. In the centuries we are considering, there was an active process of separating the main definitions and categories of ethics [11, c.6974]. Ethics as an independent scientific system was primarily formed only at the end of the 17th century; As for the final formulation of science, this process received its logical continuation up to the 20th century, when J. Moore - one of the most influential thinkers of modern Anglo-American philosophy, who held the positions of intuitionism, in his fundamental work "Principia Ethica" (Principles of Ethics), devoted to the problems of mega-ethics, defended the concept of autonomous ethics, which cannot be substantiated at the expense of any other reality, including religion, and the consideration of which rests on the analysis of its language, which connects Moore's ethical theory with the entire system of his views. remains one of the most fundamental for the 20th century, despite the fact that it preserves ethics as an independent structured area of philosophical knowledge. Thomas Hobbes, for example, regarded ethics not as a science in its own right, but as one that links philosophy to social theory. The basis of ethics, according to Hobbes, is the natural laws and their manifestations in man. Here the empirical nature of the scientist's philosophy is traced. Therefore, Hobbes, in a fundamental difference from his medieval predeces- 
sors, sees nothing wrong with the fact that morality and ethics proceed, first of all, from the natural inclinations of a person as self-preservation, the realization of natural needs. Good and good for Hobbes is what a person strives for, what he desires. Evil is what he does not like and what he avoids. From the point of view of the general theory, the ethicist Hobbes considers the main ethical categories - good, moral evil, etc. - to be relative concepts. This already led to a sharp disagreement with the philosophers of previous times, as well as with his contemporaries, but not empiricists. Hobbes's ethical views were most closely influenced by his political views. Human virtue (or vice), he believed, depends on how reasonable the members of society are, how much they contribute or hinder the realization of the good. Since, according to Hobbes, the state is created as a result of a voluntary social contract, the duties of the members of society coincide with the morality that is laid down in the basis of the social contract and is provided for by it. Failure to comply with moral and ethical requirements (that is, violation of the rules of ethics) should be punished by punishments of various degrees as non-compliance with the provisions of the social contract. Hobbes considered the stability of the system to be the most important goal of society, therefore he identified morality and its laws with civic virtues. Thus, ethics served as the moral foundation of his philosophy for Hobbes, it supported the new science and rejected abstractly sterile ethical ideas.

John Locke was quite close to Hobbes, if we take into account the general spread of opinions on ethics in world philosophy. Locke somewhat idealized ethics, he believed that it could be a science similar to mathematics. Being an empiricist in his worldview, Locke believed that good is what brings pleasure, and evil is what causes suffering. Therefore, happiness is about getting more pleasure and less suffering. Therefore, according to Locke, the pursuit of happiness is a natural and understandable process. All human activity should be free, and the goal of individual freedom is the pursuit of individual and common good. Despite the fact that Locke understood morality, happiness, goodness and other ethical categories in a somewhat simplified way, his ethics also fundamentally differs from the ethics of the Middle Ages and is based on the rational inclinations of a person, and not useless theological prejudices. Locke believed that the true basis of morality is the divine will, which finds its direct embodiment in the laws governing social life. Therefore, morality for him was nothing more than awareness and reasonable obedience to these laws. Locke considered a necessary condition for the existence and prosperity of society to combine, harmony of the needs of each individual with the interests of society as a whole. Throughout the ethical philosophy of Hobbes, there is also the presence of empiricism and the defense of constitutional monarchy.

Ethics in English philosophy has had a strong influence on the philosophical and socio-political thought of other countries. F. Bacon, Hobbes, Locke, 
and the British, and leading scientists and public figures of other countries were read: Toland, Priestley, Berkeley, Hume, Voltaire, Condillac, Lametrie, Helvetius, Diderot, etc. One thing is that the English empiricists in their ethical views where directly, and where indirectly acknowledged the mortality of the human soul produced confusion in the minds of their contemporaries and subsequent generations. The main basis for this was a new experimental science, a new understanding of nature, the world, space, and man. Therefore, we must agree that the European XVIII century, which we call the Age of Enlightenment and the Age of Reason, began in England. From there, the spirit of the new philosophy spread throughout Europe, supported by examples of real changes in the social structure.

Thus, the divine understanding of the world, the world built according to God's understanding, was destroyed. But it was destroyed in a different way. If in the Middle Ages such destruction was carried out only theoretically and a priori, and was brutally persecuted as heretical, now, in the era of the Enlightenment, this destruction was carried out in fact, empirically, on the basis of experiments and practical evidence. Supporters of the previous vision of the world - religious leaders and thinkers could not deny the natural scientific discoveries, for these discoveries were reality and were perceived by the broad masses as correct, true. Then religious leaders adopted ethics and posed the question in this way - the natural-scientific picture of the world may be correct, maybe the meaning and forms of God's influence were really exaggerated, but is it ethical to reduce the existence of God to nothing, is it ethical to deny it, is it ethical for a person to pretend to omnipotence, and so on. To which empiricists and natural scientists responded in their own way: truth is the goal of a scientist's dreams and he should not stop at anything before achieving it. This also shows one of the manifestations of the ethics of the Renaissance, that is, the new ethics.

Francis Bacon, a pioneer in the development of "natural philosophy", was one of those who laid the foundation in England for the concept of "natural morality", the construction of ethics, albeit a participatory theology, but mostly without the help of religious ideas, proceeding from rationally understood worldly life aspirations and affects of the human personality. J. Locke also paid serious attention to ethics. The doctrine of the existence of innate ideas, i.e. concepts and judgments that carry knowledge, as well as innate principles that wash how one should behave, was at the time of J. Locke the basis of idealistic concepts of extrasensory and generally extra-empirical knowledge, as well as the basis of ideas about the existence of a special spiritual substance, as a seat of innate ideas ... This theory was shared by many contemporaries of J. Locke, although its roots go back to antiquity [12, c. 25]. Locke's criticism of the theory of innate ideas was the starting point of his pedagogical concept and was the starting point for Locke's entire theory of knowledge. An important role, 
the denial of the innate moral principles played in Locke's ethics: it helped him in the XX (On the modes of pleasure and pain) and XXI (On the powers and abilities) chapters of the second book "Experience ..." to draw a conclusion about the close connection of the concept of good with pleasure and benefit, and evil - with suffering and harm for man [12, c. 280-338] and thus substantiate the doctrine of the natural law of morality and further on natural law in its ethical interpretation. Locke's emphatic denial of innate ideas brings enormous benefits to the theory of knowledge in his doctrine of truth and truth.

These were the realities that should be considered when describing the situation of the era. The most important thing is that ethics, as a result, was unified, made a worldwide, unified criterion and phenomenon precisely by the philosophers of the late Renaissance. In the XIV - XVII centuries. ethics has become ethics proper in the modern sense, the meaning of the word.

The sphere of morality could not be left to the side of the general philosophical process of time, from the explosion of intellectual energy, when, as never before, time has set so acute the tasks of philosophical comprehension of everything that happens, rejection of old schemes, and renewal of the worldview. And, as a result, the appearance in the light of the deepest in thought and brilliant in the literary form of creations that affect not only the intellect of a person, but also his emotions, the entire spectrum of his spiritual abilities. It would be a shame for humanity, F. Bacon argued, if the mental world of people remained in the divisions assigned to it by antiquity, while the area of the material world was immeasurably expanding [13, c.100].

The first in historical time and line of succession is T. More, the author of the famous "Utopia". The value of the analysis of this work also lies in the fact that with all the variety of literary sources used in writing "Utopia" and testifying to the unusually wide area of the author's erudition, characteristic of him as a humanist scientist, T. More acts as a thinker who draws material not so much from the works of writers as from the very English reality of the Renaissance with its sharp social contradictions that required a radical solution. To understand the humanistic concept of T. Mora, it is very important, along with the socio-political problems of "Utopia", to highlight its ethical (and religious) aspects. From the point of view of studying the essence of the phenomenon, i.e. his socially determined vital necessity, which is fixed in the ideal norms of behavior and morality, preached by the author of "Utopia". "Investigate the essence of the phenomenon, i.e. his socially determined vital necessity, which is fixed in the ideal norms of behavior preached by the author of "Utopia" - such, in our opinion, should be the approach to this problem. "Since, no matter how we delve into the study of the constituent elements of the ideological synthesis in which the ethics of an ideal Utopia is realized, we still have to answer the question of what are the class interests that corresponded to these ideal norms 
of behavior, which received in philosophy and religion the meaning of absolute values ", notes S.D. Skazkin [14, c. 131].

This work is inextricably and deeply connected with the philosophical, ethical, socio-political ideas of humanism. And humanism, as you know, as a necessary spiritual background of the greatest cultural and historical revolution of the Renaissance, in general, and ethical and aesthetic renewal, in particular, was the basis for a decisive rethinking of complex philosophical problems associated with understanding the nature of man, his existence and development, when the problem of man became the focus of the philosophical center of comprehension, when the idea that a man can be understood without intruding into the realm of the transcendent, but only by analyzing the conditions of his real life, on which his freedom and dignity as a person depend, began to be asserted.

It is easy to replace that the main thing in Utopian ethics is the problem of happiness, and its definition as the goal of human existence is the central philosophical problem of Utopia. According to the just remark of A.H. Gorfunkel, "the understanding of God as a master, and nature as a spectacle of" majestic and amazing ", testifies to More's acceptance of the humanistic concept of a beautiful world open to human knowledge" [9, c.137]. In posing and solving this "eternal" problem, T. More reveals a thorough acquaintance with ancient Greek philosophy, in particular with Plato and Aristotle. This is evidenced by the commonality in many respects of the problems and terminology $[15$, c. 176177], especially for the classification of such important categories as pleasure. The ethical teaching of Th. More is directed "not only against the harsh stoicism, but also against the ascetic ideal perverted by the Middle Ages: the Utopians consider it a sign of extreme insanity, excessive cruelty to oneself and the highest ingratitude toward nature, if someone despises the granted beauty, weakens strength, turns his agility into laziness" [9, c.139]. The religious beliefs of the inhabitants of an ideal society are also in harmony with these ethical views; this is especially true of the principle of broad religious tolerance.

\section{Conclusion}

Each epoch has its own worldview, depending on the level of knowledge and the nature of civilization, on the historical experience of a given people. The highest synthesis of linguo-culture is carried out by philosophy. Between the philosophy (and ethics) of each era and other forms of social consciousness, relations of interdependence and interdependence are formed. This establishes a specific historical orientation and the very content of the development of ethics (as part of philosophy), thereby forming a special style of thinking inherent in each era, which is a generalized image of culture as an integral process, within certain space-time constraints. 
The brightest representatives of the philosophical thought of the Renaissance and the New Age were completely unanimous in their desire to create and substantiate scientific philosophy, since they saw in science a new phenomenon unknown to the past, the highest form of all possible knowledge. And it was a consciousness of necessity dictated by a new historical era, from the standpoint of which ancient wisdom did not seem at all to be a science.

The study of the history of ethical and philosophical thought shows that the development of theoretical problems of our time is unthinkable without the development of the cultural and spiritual heritage of the past. And the deeper we delve into the past, the better we will understand the present and the future. History deals not only with what has passed into the past, but also with the living life of our time. And that is why we will never lose interest in what we argued about, what our predecessors thought, in their search and flight of thought. This is a fair attitude to the history of philosophy, the stages of its evolution. It is in the light of this approach that it can be stated that the formation of the philosophy of the Renaissance is the main result of this historical and philosophical process, and its further development as an important component of world philosophy is its main historical perspective.

\section{List of references}

1 Овсянников М.Ф. История эстетической мысли. - М.: Искусство, 1984. $335 \mathrm{c}$.

2 Шталь И.В. Художественный мир гомеровского эпоса. - М.: Наука, 1983, 296 c.

3 Культура Возрождения и общество. - М.: Наука, 1986. - 232 с.

4 Мир философии. Ч.2. - М.: Политиздат, 1991. - 554 с.

5 Mc Dowell A. Meaning, Knowledge and Reality. - London, 1998. - 291 p.

6 Гуревич А.Я. Категории средневековой культуры. - М.:, 1972. - 318 с.

7 Богомолов А.С., Ойзерман Т.И. Основы теории историко-философского прогресса. - М.: Наука, 1983. - 288 с.

8 Фролов И.Т. Перспективы человека. - М.: Мысль, 1979. - 336 с.

9 Горфункель А.Х. Философия эпохи Возрождения. - М: Высшая школа, 1980. - 368 c.

10 Parry R. Ancient Ethical Theory. In: The Stanford Encyclopedia of Philosophy. Fall 2014 Edition. Accessed Jan.28, 2020. https://plato.stanford.edu/archives/fall 2014/entries/ethics-ancient/.

11 Shadmanov K.B. On the Linguo-Philosophical Nature of Socio-Ethical Vocabulary. In: Skase Journal of Literary and Cultural Studies (SJLCS), Vol.2.-2020, N1.(Slovakia). - P. 69-74.

12 Локк Джон. Соч. в 3-х т. Т.1. - М.: Мысль, 1985. - 621с.

13 Бэкон Френсис. Соч. в 2-х т. - Т.2. - М.: Мысль, 1972. - 582 с. 
14 Сказкин С.Д. К вопросу о методологии истории Возрождения и гуманизма. - CB, XI, 1958. - С. 131.

15 Осиновский И.Н. Томас Мор: Утопический коммунизм, гуманизм, реформация. - М.: Наука, 1978. - 327 с.

\section{Transliteration}

1 Ovsyannikov M.F. Istoriya esteticheskoy mysli [The History of Ethical Thought]. - M.1984. $-335 \mathrm{~s}$.

2 Shtal' I.V. Khudozhestvennyy mir gomerovskogo eposa [The Artistic World of Homerian Epos]. - M.: Nauka, 1983. - 296 s.

3 Kul'tura Vozrozhdeniya i obshchestvo [Renaissance Culture and Society]. - M.: Nauka, 1986. - $232 \mathrm{~s}$.

4 Mir filosofii [The World of Philosophy]. CH.2. - M., 1991. - 554 s.

5 Mc Dowell A. Meaning, Knowledge and Reality. - London, 1998. - 291 p.

6 Gurevich A.YA. Kategorii srednevekovoy kul'tury [Medieval Cultural Categories]. - M., 1972. - $318 \mathrm{c}$.

7 Bogomolov A.S., Oyzerman T.I. Osnovy teorii istoriko-filosofskogo progressa [The Basics of Historical and Philosophical Progress Theory]. - M.: Nauka, 1983. $288 \mathrm{c}$.

8 Frolov I.T. Perspektivy cheloveka [Human Prospects ]. - M., 1979. - 336 s.

9 Gorfunkel' A.KH. Filosofiya epokhi Vozrozhdeniya [Philosophy of Renaissance]. - M., 1980. - $368 \mathrm{~s}$.

10 Parry R. Ancient Ethical Theory. In: The Stanford Encyclopedia of Philosophy. Fall 2014 Edition. Accessed Jan.28, 2020. https://plato.stanford.edu/archives/fall 2014/entries/ethics-ancient/.

11 Shadmanov K.B. On the Linguo-Philosophical Nature of Socio-Ethical Vocabulary. In: Skase Journal of Literary and Cultural Studies (SJLCS), Vol.2. - 2020, N1.(Slovakia). - P. 69-74.

12 Lokk Dzhon. Soch. v 3-kh t. T.1. - M.: Mysl', 1985. - 621c.

13 Skazkin S.D. K voprosu o metodologii istorii Vozrozhdeniya i gumanizma [To the Issue of Renaissance and Humanism History Methodology]. - SV, XI, 1958. - C. 131.

14 Bekon Frensis. Soch. v 2-kh t. T.2. - M.: Mysl', 1972. - 582 s.

15 Osinovskiy I.N. Tomas Mor: Utopicheskiy kommunizm, gumanizm, reformatsiya [Thomas More: Utopian Communism, Humanism, Reformation], - M.: Nauka, 1978. $-327 \mathrm{~s}$.

\section{Шадманов К.Б. \\ Философия позднего Возрождения Англии: нравственность человека}

Аннотация. Автором исследования ставится цель наглядно показать временной период развития морально-этических законов, принципов и 
концепций, которые выявлялись и формировались в разных странах, среди различных народов в течение тысячелетий человеческой истории. Отдельным предметом исследования выступает английская философия позднего Ренессанса. Английская философская традиция представлена одними из наиболее выдающихся учений о человеке и его природе. Исследование отражает особенности и национальную самобытность процесса формирования этики в Англии во время позднего Ренессанса.

Ключевые слова: позднее Возрождение, категория, индивид, человек разумный, форма, общественное бытие, конкретно-исторический, национальный.

\section{Шадманов К.Б.}

\section{Ұлыбританиядағы кейінгі Қайта өрлеу философиясы: адамның адамгершілігі}

Aңдатna. Автор адамзат тарихындағы мыңдаған жылдар бойы әртүрлі елдерде, әр-түрлі халықтар арасында анықталған және қалыптасқан моральдықэтикалық заңдардың, қағидалар мен тұжырымдамалардың даму кезеңін көрсету мақсатын қойды. Зерттеудің пәні ретінде кейінгі Қайта өрлеу дәуірінің ағылшын философиясы қарастырылады. Ағылшындық философиялық дәстүр адам мен оның табиғаты туралы ең көрнекті ілімдердің бірі болып ұсынылды. Зерттеу кейінгі Ренессанс дәуіріндегі Ұлыбританиядағы этиканың қалыптасу үдерісіндегі ұлттық және өзіндік ерекшеліктерін көрсетеді.

Tүйін сөздер: кейінгі Қайта өрлеу, категория, жеке тұлға, сапалы адам, форма, қоғамдық болмыс, нақты тарихи, ұлттық. 